\title{
Penerapan Metode Fuzzy Mamdaniuntuk Menentukan Jumlah Pendapatan Pegadaian Berdasarkan Jumlah Omset dan Harga Emas serta Kurs
}

\author{
Rahmawati $^{*}$, Rahima Dina ${ }^{2}$, Wartono ${ }^{3}$ \\ ${ }^{1}$ Program Studi Matematika, Universitas Islam Negeri Sultan Syarif Kasim Riau, Pekanbaru, \\ Indonesia;* rahmawati@uin-suska.ac.id \\ ${ }^{2}$ Program Studi Matematika, Universitas Islam Negeri Sultan Syarif Kasim Riau, Pekanbaru, \\ Indonesia; 11754201916@student.uin-suska.ac.id \\ ${ }^{3}$ Program Studi Matematika, Universitas Islam Negeri Sultan Syarif Kasim Riau, Pekanbaru, \\ Indonesia; wartono@uin-suska.ac.id
}

\begin{abstract}
Abstrak. Penelitian ini bertujuan untuk memprediksi jumlah pendapatan pada satu periode berdasarkan jumlah omset, harga emas dan kurs di Pegadaian Syariah Cabang Subrantas Unit Tanah Merah Pekanbaru. Teknik analisa yang digunakan adalah metode fuzzy Mamdani. Penelitian ini dimulai dengan menentukan himpunan fuzzy, fungsi implikasi, komposisi aturan dan defuzzifikasi dalam menentukan jumlah pendapatan. Hasil penelitian ini menunjukkan bahwa prediksi jumlah pendapatan pegadaian dengan nilai keakuratan mencapai 87,4632\%.

Kata Kunci: jumlah pendapatan, jumlah omset, harga emas, kurs, fuzzy Mamdani
\end{abstract}

Abstract. This study aims to predict the amount of income in one period based on the amount of turnover, the price of gold and the exchange rate at the Pegadaian Syariah Branch Subrantas Unit Tanah Merah Pekanbaru. The analysis technique used is the Mamdani fuzzy method. The results of this study indicate that the predicted total pegadaian income with an accuracy value reached $87.4632 \%$

Keywords: Iincome, turnover, gold price, exchange rate, fuzzy Mamdani

\section{Pendahuluan}

Pegadaian adalah sebuah BUMN sektor keuangan Indonesia yang bergerak pada tiga lini bisnis perusahaan yaitu pembiayaan, emas dan aneka jasa. Pegadaian merupakan salah satu alternatif bagi masyarakat untuk mendapatkan kredit baik skala kecil maupun besar dengan pelayanan yang mudah, cepat, dan aman. Kondisi suatu perusahaan dapat dilihat melalui laporan keuangan, dimana selanjutnya itu menjadi suatu informasi yang menggambarkan kinerja keuangan. Kinerja keuangan dikatakan stabil apabila pendapatan suatu perusahaan mencapai target yang telah ditentukan. Pendapatan merupakan keseluruhan dana yang masuk dari penjualan produk baik jasa maupun barang. 
Pendapatan pegadaian merupakan segala hasil dari produk layanan yang dilakukan di pegadaian. Pendapatan suatu perusahaan dapat dipengaruhi oleh faktor eksternal dan internal. Faktor internal diantaranya leverage operasi, umur perusahaan, jumlah omset, ukuran perusahaan (Rice, 2014). Sedangkan faktor eksternal dapat dilihat dari pertumbuhan ekonomi suatu negara, tingkat inflasi, nilai tukar rupiah (kurs), harga emas dan harga minyak dunia (Untono, 2015).

Beda halnya dengan pendapatan, omset adalah perhitungan total penjualan yang ada selama jangka waktu yang diberikan dapat berupa bulanan, triwulan maupun setahun. (Teeuw, 2005) Omset adalah salah satu variabel yang diperkirakan dapat mempengaruhi pendapatan suatu perusahaan. Harga emas juga menjadi salah satu variabel yang mempengaruhi pendapatan pegadaian dikarenakan emas merupakan produk layanan utama. Selama ini harga emas di Indonesia cenderung naik dan ketika mengalami penurunan, nilainya tidak terlalu signifikan. Hal tu terjadi karena ketika emas dalam harga dolar Amerika Serikat (AS) turun, pada saat yang sama harga dolar AS cenderung menguat.

Ketika harga emas dalam dolar AS naik maka ini berpengaruh pada nilai tukar rupiah. Menurut (Mudrajat, 2001) nilai tukar rupiah adalah nilai tukar sejumlah rupiah yang diperlukan untuk membeli satu US Dollar dengan ditentukan oleh permintaan dan penawaran terhadap kurs. Harga emas dan kurs saling mempengaruhi sehingga mengakibatkan nilai mata rupiah menurun tetapi juga menurunkan daya beli masyarakat karena harga bahan pokok meningkat. Sehingga ini akan menyebabkan kurangnya minat masyarakat untuk melakukan pegadaian ataupun membeli produk-produk layanan yang ada di pegadaian sehingga mengakibatkan berkurangnya pendapatan dari pegadaian.

Dalam menentukan jumlah pendapatan suatu perusahaan dapat menggunakan sistem pendukung keputusan (fuzzy inference system). Dalam sistem pendukung keputusan fuzzy terdapat beberapa metode yang dapat digunakan seperti metode fuzzy Tsukamoto, metode fuzzy Sugeno, metode fuzzy Mamdani dan sebagainya.

Beberapa penelitian terdahulu yang telah menggunakan metode fuzzy Mamdani ini, diantara penelitian sebelumnya yaitu, oleh (Fajar, 2011) dalam mengoptimasi produksi barang menggunakan metode Mamdani dan metode Sugeno menunjukkan hasil analisis pembanding yang paling Copyright $(0) 2020$

\section{Buana Matematika :}

Jurnal Ilmiah Matematika dan Pendidikan Matematika 
mendekati nilai kebenaran produksi barang adalah menggunakan metode fuzzy Mamdani dengan melihat tingkat permintaan dan persediaan. Penelitian dilanjutkan oleh (Saleh, 2015) dalam memprediksi tingkat kebisingan lalu lintas dengan metode fuzzy Mamdani menunjukkan nilai presentasi error sangat kecil yaitu sebesar 2,39\% dengan variabel input lebar jalan, jumlah kendaraan dan tingat koreksi.Penelitian selanjutnya dilakukan oleh (Murni et al., 2016) menunjukkan bahwa peneliti berhasil merencanakan agar produksi roti menjadi lebih cepat, tepat dan efisien dengan menggunakan metode fuzzy Mamdani dilihat dari jumlah permintaan dan jumlah persediaan.

Kemudian penelitian dilakukan oleh (Hanifah, 2017) menunjukkan bahwa peneliti dapat membantu dalam meningkatkan jumlah produksi gula pasir berdasarkan kriteria luas lahan, randemen, jumlah tebu, hablur, jam mesin, jam giling dan bahan pembantudengan menggunakan metode fuzzy Mamdani. Sama halnya dengan penelitian yang dilakukan oleh peneliti (Munawaroh et al., 2019) dalam menentukan kriteria penilaian bagi siswa yang berhak mendapat beasiswa dengan menggunakan metode fuzzy Mamdani menghasilkan daftar siswa yang layak dan tepat sasaran secara tepat dan akuratyang dipengaruhi oleh kriteria rata-rata nilai rapor, pendapatan orang tua dan jumlah tanggungan orang tua. Penelitian dilanjutkan (Rahmawati et al., 2019) dalam memprediksi jumlah pembelian obat dengan metode Mamdani dilihat dari tingkat persediaan dan penjualan yangmenunjukkan hasil tingkat keakuratan sebesar 99,35869\%.

Pada umumnya peforma perusahaan dilihat dari kestabilan kinerja keuangan. Kinerja keuangan perusahaan meliputi pendapatan yang dapat dipengaruhi oleh omset (faktor internal) maupun harga emas dan kurs (faktor eksternal). Naik dan turunnya harga emas sangat mempengaruhi jumlah taksiran barang lainnya, dan berdampak pada pendapatan pegadaian. Semakin tinggi harga emas semakin tinggi omset dan akan berdampak semakin tinggi pula pendapatan yang akan didapat oleh pegadaian. Namun, dalam data yang diperoleh dari pegadaian tidak selalu menggambarkan bahwa ketika harga emas dan kurs meningkat, maka meningkat pula pendapatan yang diperoleh oleh Pegadaian. Dapat dilihat bahwasannya 5 tahun terakhir ini pada tahun 2015 harga emas mengalami kenaikan namun pandapatan mengalami penurunan dan kenaikan. 
Dalam hal ini akan digunakan metode fuzzy Mamdani dalam memprediksi jumlah pendapatan berdasarkan jumlah omset, harga emas dan kurs pada Pegadaian Syariah Cabang Subrantas Unit Tanah Merah Pekanbaru tahun 2015-2019untuk meningkatkan kualitas suatu perusahaan karena memiliki tingkat keakuratan yang lebih tepat daripada metode sistem inferensi fuzzy lainnya.

\section{Metode}

Tahap-tahap yang dilakukan dalam penelitian ini adalah identifikasi masalah, pengumpulan data dan penentuan jumlah pendapatan. Pada tahap identifikasi masalah, permasalahan yang dibahas dalam penelitian ini adalah menentukan jumlah pendapatan menggunakan fuzzy Mamdani. Pada tahap pengumpulan data dilakukan pengumpulan data sekunder dari pegadaian syariah cabang subrantas unit tanah merah Pekanbaru.

Pada tahap selanjutnya akan dilakukan penentuan jumlah pendapatan, yaitu proses memprediksi jumlah pendapatan dengan tiga variabel input menggunakan fuzzy inference system yakni metodefuzzy Mamdani memiliki algoritma sebagai berikut :

1. Menentukan himpunan fuzzy pada setiap variabel input dan output.

2. Memperoleh Fungsi Implikasi dengan aturan MINmemiliki bentuk umum sebagai berikut : Jika a adalah $A_{i}$ dan b adalah $B_{i}$ maka $c$ adalah $C_{i}$.

Dengan $A_{i}, B_{i}$ dan $C_{i}$ adalah predikat-predikat fuzzy yang merupakan nilai linguistik dari masing-masing variabel.

3. Membuat Komposisi Aturan dengan aturan $M A X$, kemudian menggunakan nilai tersebut untuk memodifikasi daerah fuzzy dan mengaplikasikannya ke ouput.

4. Menentukan Defuzzifikasi dengan metode centroid dimana solusi tegas diperoleh dengan cara mengambil titik pusat daerah fuzzy. Secara umum dapat dituliskan :

$Z_{0}=\frac{\int_{a}^{b} Z \mu(z) d z}{\int_{a}^{b} \mu(z) d z}=\frac{M_{1}+M_{2}+M_{3}}{A_{1}+A_{2}+A_{3}}$

Untuk domain kontinu, dengan :

$Z_{0} \quad$ = nilai hasil defuzzifikasi

$\mu(z)=$ derajat keanggotaan titik tersebut

$z=$ nilai domainke-i

$M=$ Momen

$A=$ Luas

Copyright $@ 2020$

Buana Matematika :

Jurnal Ilmiah Matematika dan Pendidikan Matematika 
4. Menentukan nilai MSE (Mean Square Error)

$$
\begin{aligned}
M S E & =\frac{\sum\left(z_{i}-\hat{z}_{i}\right)^{2}}{n} \\
\text { dimana : } & \\
z_{i} & =\text { nilai data asli amatanke-i } \\
\hat{z}_{i} & =\text { nilai ramalan amatanke-i } \\
n & =\text { banyak data }
\end{aligned}
$$

5. Menentukan nilai MAPE (Mean Absolute Percentage Error)yaitu suatu ukuran akurasi peramalan dari suatu metode peramalan. Secara umum dapat ditulis :

$$
\begin{aligned}
\text { MAPE } & =\frac{\sum_{i=1}^{z}\left|z_{i}-\hat{z}_{i}\right|}{n} \times 100 \% \\
z_{i} & =\text { nilai data asli amatanke-i } \\
\hat{z}_{i} & =\text { nilai ramalan amatanke-i } \\
n & =\text { banyak data }
\end{aligned}
$$

DenganKriteria nilai MAPE menurut (Chang et al., 2007) adalah :
a. $<10 \%$ (kemampuan peramalan sangatbaik)
b. $10 \%-20 \%$ (kemampuan peramalanbaik)
c. $20 \%-50 \%$ (kemampuan peramalan cukup)
d. $>50 \%$ (kemampuan peramalan buruk)

6. Menentukan tingkat kebenaran suatu peramalan dengan menggunakan rumus :

Tingkat Kebenaran $=100 \%-$ MAPE

Diagram alir program (flowchart) berguna untuk menunjukkan alir (flow) di dalam program atau prosedur sistem secara. Adapun flowchart yang diterapkan dalam program ini adalah sebagai berikut: 


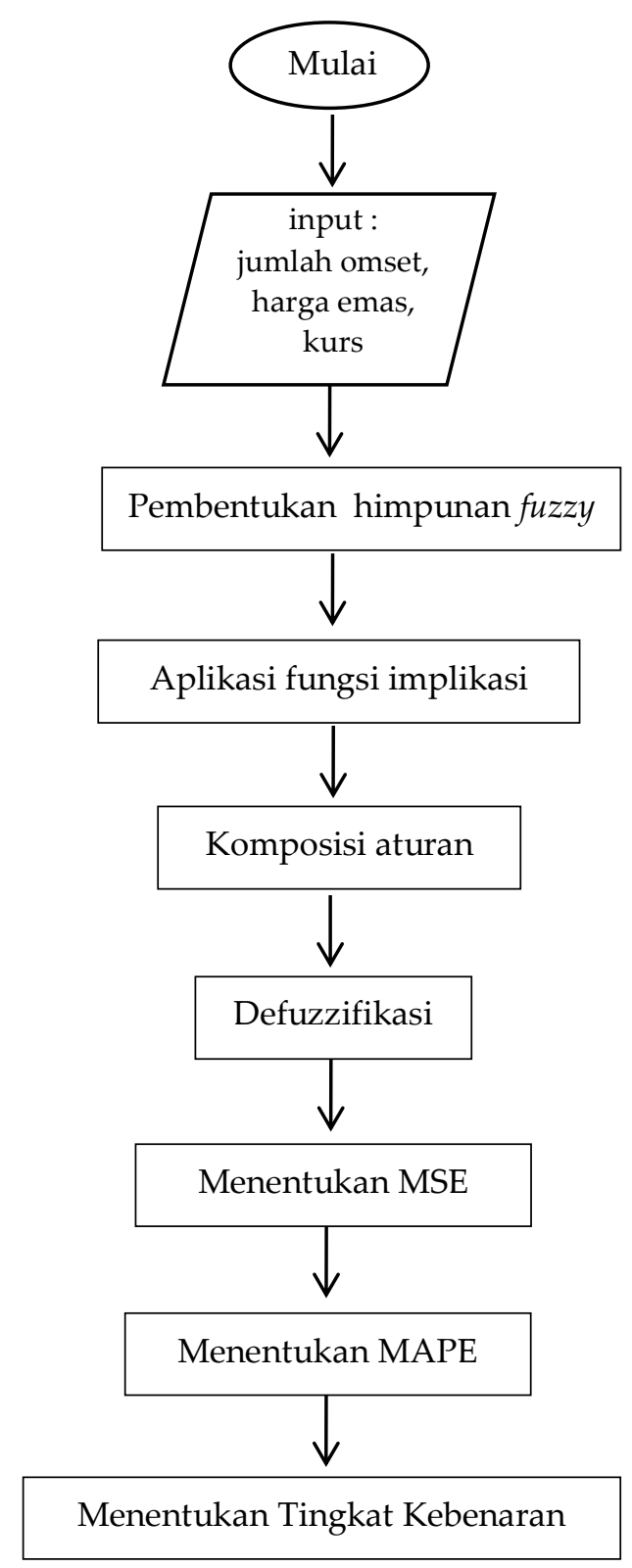

Gambar 1. Flowchart prediksi jumlah pendapatan

\section{Hasil dan Pembahasan}

Data yang diolah adalah data jumlah omset, harga emas dan kurs di Pegadaian Syariah Cabang Subrantas Unit Tanah Merah Pekanbaru pada tahun 2015-2019 dapat dilihat pada Tabel 1 berikut ini.

\section{Buana Matematika :}

Jurnal Ilmiah Matematika dan Pendidikan Matematika 
Tabel 1. Data Jumlah Omset, Harga Emas, Kurs dan pendapatan.

\begin{tabular}{|r|c|c|c|c|}
\hline Tahun & $\begin{array}{c}\text { Jumlah Omset } \\
\text { (Rp) }\end{array}$ & Harga Emas (Rp) & Kurs (Rp) & $\begin{array}{c}\text { Jumlah Pendapatan } \\
\text { (Rp) }\end{array}$ \\
\hline $\mathbf{2 0 1 5}$ & 19.101 .261 .272 & 525.587 & 13.477 & 1.651 .004 .318 \\
\hline $\mathbf{2 0 1 6}$ & 20.191 .130 .771 & 549.667 & 13.329 & 1.701 .443 .228 \\
\hline $\mathbf{2 0 1 7}$ & 19.028 .650 .780 & 607.161 & 13.399 & 1.606 .004 .226 \\
\hline $\mathbf{2 0 1 8}$ & 21.073 .268 .255 & 660.696 & 14.247 & 1.638 .607 .518 \\
\hline $\mathbf{2 0 1 9}$ & 24.442 .794 .507 & 722.582 & 14.112 & 2.020 .929 .567 \\
\hline
\end{tabular}

Sumber: Pegadaian Syariah Cabang Subrantas Unit Tanah Merah Pekanbaru. Data emas pedagaian.co.id. Data Historis USD/IDR investing.com

Berdasarkan minimal dan maksimal dari variabel input maupun variabel output dapat dilihat pada Tabel 2 sebagai berikut.

Tabel 2. Data jumlah nilai dominan variabel

\begin{tabular}{|c|c|c|}
\hline Fungsi & Nama Variabel & Domain \\
\hline Input & Jumlah Omset & {$[19.028 .650 .780 ; 24.442 .794 .507]$} \\
\hline & Harga Emas & {$[525.587 ; 722.582]$} \\
\hline & Kurs & {$[13.329 ; 14.247]$} \\
\hline Output & Jumlah pendapatan & {$[1.606 .004 .226 ; 2.020 .929 .567]$} \\
\hline
\end{tabular}

Setelah ditentukan pembentukan aturan output dengan menganalisa data terhadap batas serta himpunan fuzzy serta nilai lingiuistik sehingga terdapat 8 aturan fuzzy pada Tabel 3 berikut ini.

Tabel 3. Hasil Aturan yang terbentuk pada inferensi fuzzy

\begin{tabular}{|c|c|c|c|c|}
\hline \multirow{3}{*}{ No. } & \multicolumn{4}{|c|}{ Variabel } \\
\hline & \multicolumn{3}{|c|}{ Input } & Output \\
\hline & Jumlah Omset & Harga Emas & Kurs & $\begin{array}{c}\text { Jumlah } \\
\text { Pendapatan }\end{array}$ \\
\hline 1 & Menurun & Turun & Turun & Berkurang \\
\hline 2 & Menurun & Naik & Turun & Berkurang \\
\hline 3 & Menurun & Turun & Naik & Berkurang \\
\hline 4 & Menurun & Naik & Naik & Bertambah \\
\hline 5 & Meningkat & Turun & Turun & Berkurang \\
\hline 6 & Meningkat & Naik & Turun & Bertambah \\
\hline 7 & Meningkat & Turun & Naik & Bertambah \\
\hline 8 & Meningkat & Naik & Naik & Bertambah \\
\hline
\end{tabular}

\section{Buana Matematika :}

Jurnal Ilmiah Matematika dan Pendidikan Matematika 
Masalah diatas diselesaikan menggunakan Metode fuzzy Mamdani dengan tahap-tahap berikut ini :

\section{Pembentukan Himpunan Fuzzy}

a. Jumlah Omset(s), terdiri dari 2 himpunan fuzzy, yaitu menurun dan meningkat. Maka fungsi Keanggotaan dirumuskan sebagai berikut:

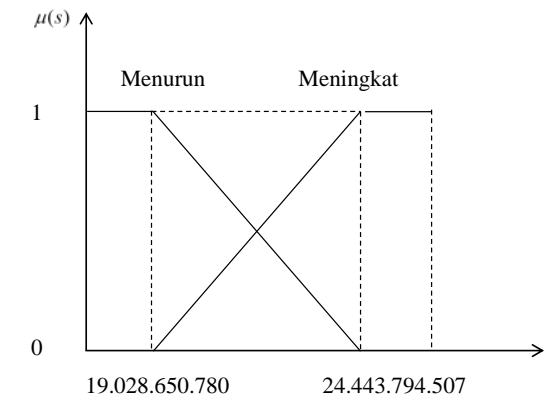

Gambar 2. Fungsi keanggotaan dari variabel Jumlah Omset

Fungsi Keanggotaan :

$$
\begin{aligned}
& \mu_{\text {menurun }}(s)=\left\{\begin{array}{cl}
1 & ; s<19.028 .650 .780 \\
\frac{24.442 .794 .507-}{24.442 .794 .507-19.028 .650 .780} & ; 19.028 .650 .780 \leq s \leq 24.442 .794 .507 \\
0 & ; s>24.442 .794 .507
\end{array}\right. \\
& \mu_{\text {meningkat }}(s)=\left\{\begin{array}{cl}
0 & ; s<19.028 .650 .780 \\
\frac{s-19.028 .650 .780}{24.442 .794 .507-19.028 .650 .780} & ; 19.028 .650 .780 \leq s \leq 24.442 .794 .507 \\
1 & ; s>24.442 .794 .507
\end{array}\right.
\end{aligned}
$$

b. Harga emas $(x)$, terdiri dari 2 himpunan fuzzy, yaitu Turun dan Naik. Maka fungsi keanggotaan dirumuskan sebagai berikut :

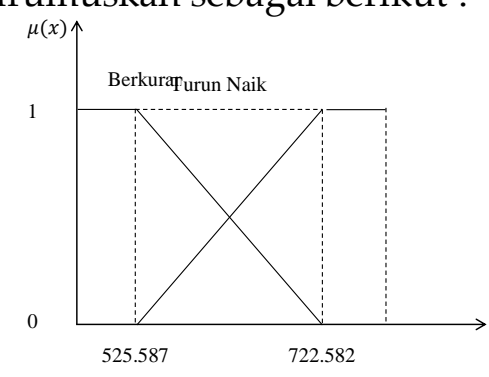

Gambar 3. Fungsi keanggotaan dari variabel harga emas

Copyright (C) 2020

Buana Matematika :

Jurnal Ilmiah Matematika dan Pendidikan Matematika 
Fungsi Keanggotaan :

$$
\begin{aligned}
& \mu_{\text {turun }}(x)=\left\{\begin{array}{cl}
1 & ; x<525.587 \\
\frac{722.582-\mathrm{x}}{722.582-525.587} & ; 525.587 \leq x \leq 722.582 \\
0 & ; x>722.582
\end{array}\right. \\
& \mu_{\text {naik }}(x)=\left\{\begin{array}{cl}
0 & ; x<525.587 \\
\frac{\mathrm{x}-525.587}{722.582-525.587} & ; 525.587 \leq x \leq 722.582 \\
1 & ; x>722.582
\end{array}\right.
\end{aligned}
$$

c. Kurs (y), terdiri dari 2 himpunan fuzzy, yaitu Turun dan Naik. Maka rumus keanggotaan dirumuskan sebagai berikut :

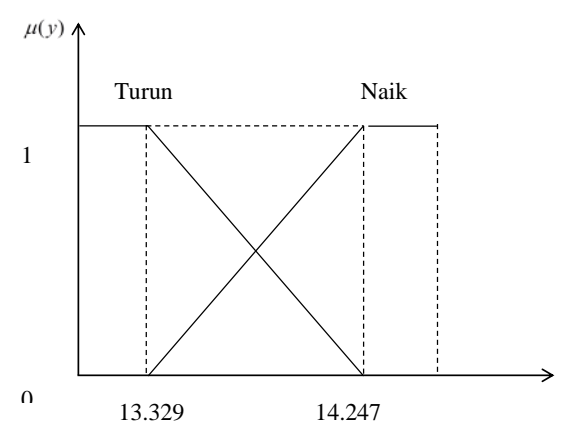

Gambar 4. Fungsi Keanggotaan dari Variabel Kurs

Fungsi Keanggotaan :

$$
\begin{gathered}
\mu_{\text {turun }}(y)=\left\{\begin{array}{cl}
1 & ; y<13.329 \\
\frac{y-13.329}{14.247-13.329} & ; 13.329 \leq y \leq 14.247 \\
0 & ; y>14.247
\end{array}\right. \\
\mu_{\text {naik }}(y)=\left\{\begin{array}{cl}
0 & ; y<13.329 \\
\frac{y-13.329}{14.247-13.329} & ; 13.329 \leq y \leq 14.247 \\
1 & ; y>14.247
\end{array}\right.
\end{gathered}
$$


d. Jumlah pendapatan(z), terdiri dari 2 himpunan fuzzy, yaitu Berkurang dan Bertambah.Maka rumus keanggotaan dirumuskan sebagai berikut :

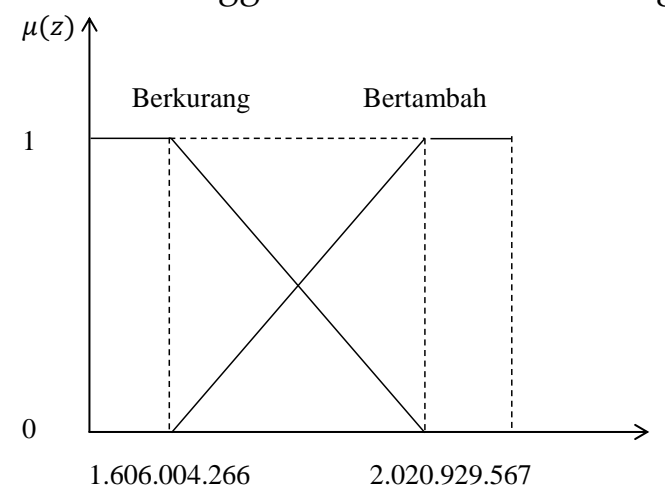

Gambar 5. Fungsi keanggotaan dari variabel jumlah pendapatan

Fungsi Keanggotaan :

$$
\begin{aligned}
& \mu_{\text {berkurang }}(z)=\left\{\begin{array}{cl}
1 & ; z<1.606 .004 .226 \\
\frac{2.020 .929 .567-\mathrm{z}}{2.020 .929 .567-1.606 .004 .226} & ; 1.606 .004 .226 \leq z \leq 2.020 .929 .567 \\
0 & ; z>2.020 .929 .567
\end{array}\right. \\
& \mu_{\text {bertambah }}(z)=\left\{\begin{array}{cl}
0 & ; z<1.606 .004 .226 \\
\frac{\mathrm{z}-1.606 .004 .226}{2.020 .929 .567-1.606 .004 .226} & ; 1.606 .004 .226 \leq z \leq 2.020 .929 .567 \\
1 & ; z>2.020 .929 .567
\end{array}\right.
\end{aligned}
$$

2. Fungsi Implikasi

Pada tahun 2015 didapat derajat keanggotaan setiap variabel pada Tabel 4 berikut ini.

Tabel 4. Nilai derajat Keanggotaan setiap variabel beserta nilai

\begin{tabular}{|c|c|c|c|l|}
\hline \multirow{2}{*}{ No. } & \multicolumn{3}{|c|}{ Variabel (Nilai Derajat Keangggotaan) } \\
\cline { 2 - 5 } & Jumlah Omset & Harga Emas & Kurs & \multicolumn{1}{c|}{ Output } \\
\cline { 2 - 5 } & Jumlah Pendapatan \\
\hline 1 & Menurun $(0,98)$ & Turun $(1)$ & Turun $(0,83)$ & Berkurang $(0,83)$ \\
\hline 2 & Menurun $(0,98)$ & Naik $(0)$ & Turun $(0,83)$ & Berkurang $(0)$ \\
\hline 3 & Menurun $(0,98)$ & Turun (1) & Naik $(0,16)$ & Berkurang $(0,16)$ \\
\hline 4 & Menurun $(0,98)$ & Naik (0) & Naik $(0,16)$ & Bertambah $(0)$ \\
\hline 5 & Meningkat $(0,01)$ & Turun (1) & Turun $(0,83)$ & Berkurang $(0,01)$ \\
\hline 6 & Meningkat $(0,01)$ & Naik (0) & Turun $(0,83)$ & Bertambah $(0)$ \\
\hline 7 & Meningkat $(0,01)$ & Turun $(1)$ & Naik $(0,16)$ & Bertambah $(0,01)$ \\
\hline
\end{tabular}

Copyright (c) 2020

\section{Buana Matematika :}

Jurnal Ilmiah Matematika dan Pendidikan Matematika 


\begin{tabular}{|c|c|c|c|c|}
\hline \multirow{2}{*}{ No. } & \multicolumn{4}{|c|}{ Variabel (Nilai Derajat Keangggotaan) } \\
\cline { 2 - 5 } & \multicolumn{3}{|c|}{ Input } & Output \\
\cline { 2 - 5 } & Jumlah Omset & Harga Emas & Kurs & Jumlah Pendapatan \\
\hline 8 & Meningkat $(0,01)$ & Naik $(0)$ & Naik $(0,16)$ & Bertambah $(0)$ \\
\hline
\end{tabular}

3. Komposisi Aturan

Metode yang digunakan untuk melakukan komposisi antar aturan pada setiap variabel menggunakan metode MAX. Pada Tabel 4 maka diketahui bahwa hasil komposisi aturan pada tahun 2015 yaitu :

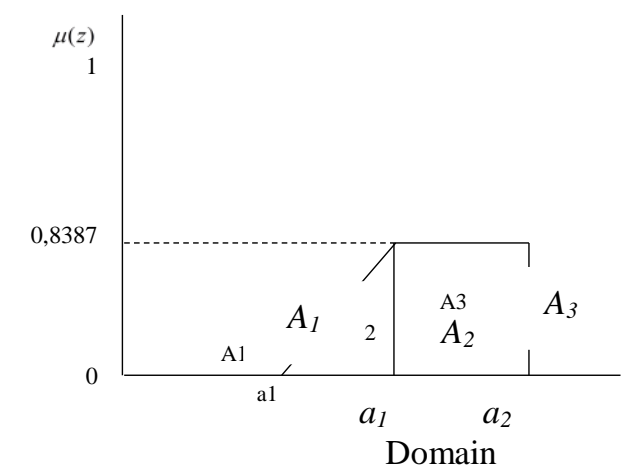

Gambar 5. Daerah hasil komposisi tahun 2015

Dengan demikian nilai $A_{1}, A_{2}, A_{3}$ akan didapat pada proses defuzzifikasi, fungsi keanggotaan untuk hasil komposisi ini adalah :

$$
\mu(z)=\left\{\begin{array}{cl}
0 & ; z<1.606 .004 .226 \\
\frac{\mathrm{z}-1.606 .004 .226}{1.282 .040 .631} & ; 1.606 .004 .226 \leq z \leq 1.954 .002 .109 \\
0,8387 & ; z>2.020 .929 .567
\end{array}\right.
$$

4. Defuzzifikasi

Metode penegasan yang akan digunakan adalah metode centroid. Untuk itu pertama-tama hitung momen untuk setiap daerah

Copyright (C) 2020

Buana Matematika :

Jurnal Ilmiah Matematika dan Pendidikan Matematika 
Berikut ini adalah hasil penyelesaian fuzzyMamdani :

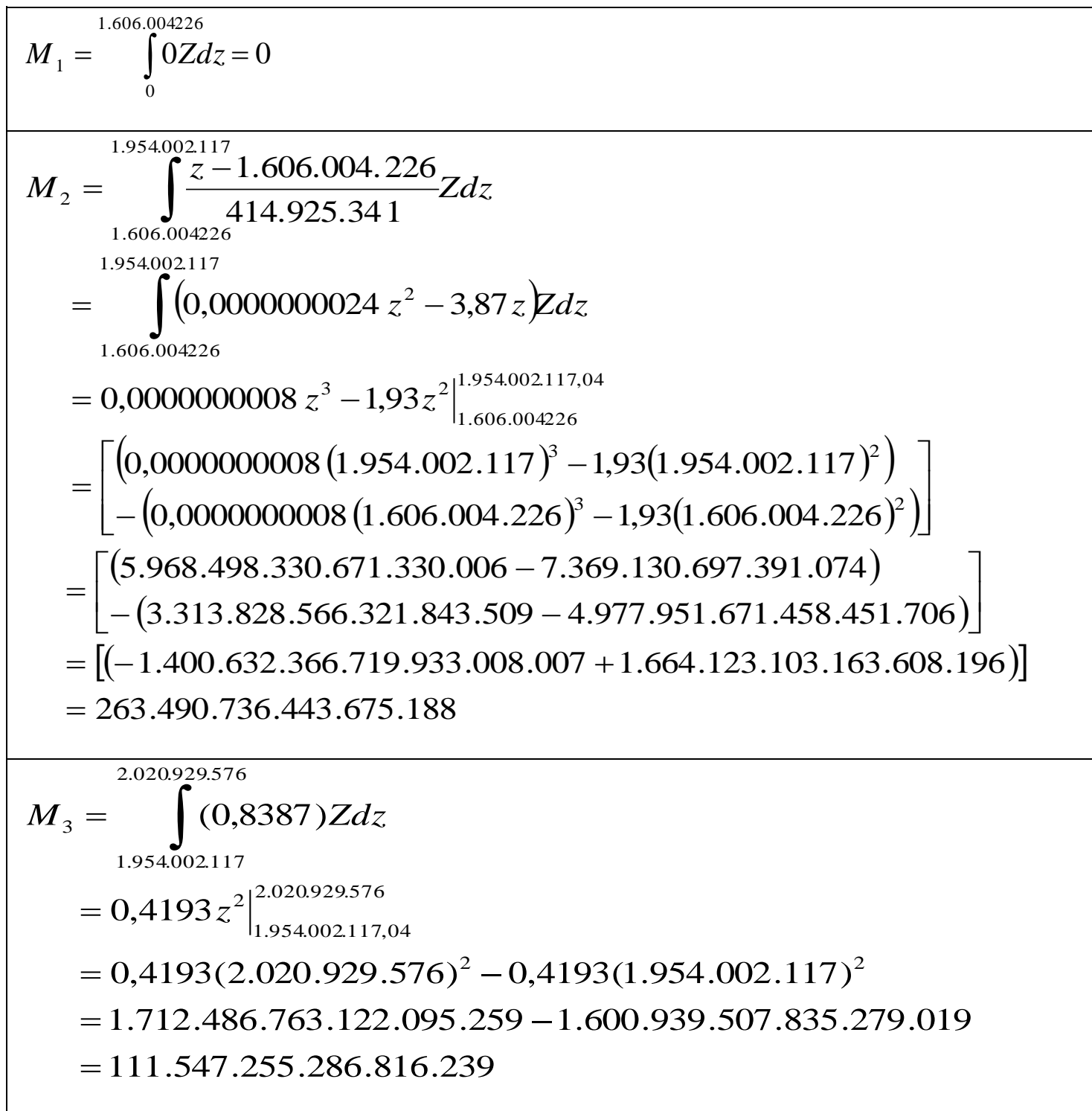

Kemudian hitung luas setiap daerah :

\begin{tabular}{|l|}
\hline$A_{1}=1.606 .004 .226(0)=0$ \\
\hline$A_{2}=(0+0,8387)(1.954 .541 .512-1.606 .004 .226) / 2=145.932 .915$ \\
\hline$A_{3}=(2.020 .929 .567-1954541512)(0,8387)=56.132 .059$
\end{tabular}

Copyright (c) 2020

\section{Buana Matematika :}

Jurnal Ilmiah Matematika dan Pendidikan Matematika 
Terakhir, gunakan rumus (2) untuk mendapatkan nilai tegasnya :

$$
\begin{aligned}
z & =\frac{M_{1}+M_{2}+M_{3}}{A_{1}+A_{2}+A_{3}} \\
& =\frac{0+263.490 .736 .443 .675 .188+111.547 .255 .286 .816 .239}{0+145.932 .915+56.132 .059} \\
z & =1.856 .026 .710
\end{aligned}
$$

Setelah melakukan semua tahap pada setiap tahun maka didapat hasil pada Tabel 5 berikut ini.

Tabel 5. Pendapatan yang diprediksi Berdasarkan input Jumlah Omset, Harga emas dan Nilai kurs

\begin{tabular}{|c|c|c|c|c|c|}
\hline Tahun & $\begin{array}{c}\text { Jumlah Omset } \\
\mathbf{( R \mathbf { p } )}\end{array}$ & $\begin{array}{c}\text { Harga } \\
\text { Emas (Rp) }\end{array}$ & $\begin{array}{c}\text { Kurs } \\
\mathbf{( R \mathbf { R } )}\end{array}$ & $\begin{array}{c}\text { Jumlah } \\
\text { pendapatan } \\
\mathbf{( R \mathbf { R } )}\end{array}$ & $\begin{array}{c}\text { Jumlah pendapatan } \\
\text { Fuzzy Mamdani } \\
\mathbf{( R \mathbf { p } )}\end{array}$ \\
\hline 2015 & 19.071 .261 .272 & 525.587 & 13.477 & 1.651 .004 .318 & 1.856 .026 .710 \\
\hline 2016 & 20.191 .130 .771 & 549.000 & 13.329 & 1.701 .443 .228 & 1.856 .164 .076 \\
\hline 2017 & 19.128 .650 .780 & 607.161 & 13.399 & 1.606 .004 .226 & 1.849 .033 .409 \\
\hline 2018 & 21.073 .268 .255 & 660.696 & 14.247 & 1.638 .607 .518 & 1.855 .974 .515 \\
\hline 2019 & 24.442 .794 .507 & 722.582 & 14.112 & 2.020 .929 .567 & 1.768 .170 .725 \\
\hline
\end{tabular}

Berdasarkan hasil penerapan metode fuzzy Mamdani maka didapat hasil perbandingan prediksi nilai logika metode fuzzy Mamdani dengan jumlah pendapatan Pegadaian Syariah Cabang Subrantas UPS Tanah Merah mengggunakan persentase rata-rata atau Mean Absolute Precentage (MAPE) sebagai berikut.

Tabel 6. Tabel Perhitungan MAPE Jumlah Pendapatan dari tahun 2015-2019

\begin{tabular}{|c|c|c|c|c|}
\hline Tahun & $\begin{array}{c}\text { Jumlah } \\
\text { pendapatan } \\
\mathbf{( R p )} \\
z_{i}\end{array}$ & $\begin{array}{c}\text { Jumlah } \\
\text { pendapatan } \mathbf{F u z z y} \\
\text { Mamdani } \\
\mathbf{( R p )} \hat{z}_{i}\end{array}$ & $\begin{array}{c}\text { Error } \\
\left|z_{i}-\hat{z}_{i}\right|\end{array}$ & $\begin{array}{c}\text { MAPE } \\
\left|\frac{z_{i}-\hat{z}_{i} \mid}{z_{i}}\right| \times 100 \%\end{array}$ \\
\hline $\mathbf{2 0 1 5}$ & 1.651 .004 .318 & 1.856 .026 .710 & 205.022 .392 & 12,41 \\
\hline $\mathbf{2 0 1 6}$ & 1.701 .443 .228 & 1.856 .164 .076 & 154.720 .848 & 9,09 \\
\hline $\mathbf{2 0 1 7}$ & 1.606 .004 .226 & 1.849 .033 .409 & 243.029 .183 & 15,13 \\
\hline $\mathbf{2 0 1 8}$ & 1.638 .607 .518 & 1.855 .974 .515 & 217.366 .997 & 13,53 \\
\hline $\mathbf{2 0 1 9}$ & 2.020 .929 .567 & 1.768 .170 .725 & 252.758 .841 & 12,50 \\
\hline Jumlah & 8.617 .988 .897 & 9.185 .369 .437 & 1.072 .898 .263 & 62,68 \\
\hline
\end{tabular}

\section{Buana Matematika :}

Jurnal Ilmiah Matematika dan Pendidikan Matematika 
Dari Tabel 6 dan Persamaan (3) maka dapat diperoleh MSE untuk memperoleh kriteria prediksi dengan mengkuadratkan setiap error dan dibagi sebanyak jumlah jumlah pendapatan tahun 2015-2019 didapat sebagai berikut :

$$
\begin{aligned}
M S E= & \frac{\sum_{I=1}^{5}\left(z_{i}-\hat{z}_{i}\right)^{2}}{5} \\
& 42.034 .181 .221 .401 .664+23.938 .540 .805 .839 .104+59.063 .183 .789 .647 .489 \\
= & \frac{+47.248 .411 .384 .798 .009+63.887 .031 .703 .663 .281}{5} \\
= & \frac{236.171 .348 .905 .340 .547}{5} \\
= & 47.234 .269 .781 .068 .109
\end{aligned}
$$

Dan menggunakan Persamaan (4) maka diperoleh persentase rata-rata atau MAPE sebagai berikut :

$$
\begin{aligned}
M A P E & =\frac{\sum_{I=1}^{5}\left|z_{1}-\hat{z}_{i}\right|}{5} \times 100 \% \\
& =\frac{62,684}{5} \\
& =12,5368 \%
\end{aligned}
$$

Menurut (Makridakis, 1999) jika nilai MAPE karena kurang dari 20\% yaitu sebesar 12,5368\% maka nilai MAPE termasuk dalam kategori baik. Selanjutnya untuk memperoleh tingkat kebenaran metode fuzzy Mamdani yaitu $100 \%-12,5368 \%=87,4632 \%$

\section{Simpulan}

Dari penelitian ini didapat hasil perhitungan rata-rata persentase kesalahan dari metode fuzzy Mamdani yang digunakan adalah 12,5368\% sedangkan tingkat kebenaran dari hasil perhitungan tersebut adalah $87,4632 \%$. Menurut (Makridakis, 1999), model yang tepat adalah model yang memiliki nilai MAPE SEKITAR 0\%-30\%. Jadi, dapat disimpulkan nilai MAPE 0\% minimal cukup dan maksimal 30\% untuk dijadikan sebagai input dari metode fuzzy. Oleh karena nilai MAPE yang diperoleh $>10 \%$ ini menunjukkan tingkat peramalan jumlah pendapatan yang telah dilakukan pada tahun 2015-2019 di Pegadaian Syariah Cabang Surantas UPS Tanah Merah menggunakan metode fuzzy Mamdani dapat dikatakan baik.

Copyright (c) 2020

\section{Buana Matematika :}

Jurnal Ilmiah Matematika dan Pendidikan Matematika 


\section{Ucapan Terima Kasih}

Dalam penelitian ini peneliti mengucapkan terima kasih kepada pihak-pihak terkait yang telah membantu dalam penyelesaian penelitian ini. Khususnya kepada Pimpinan cabang, pimpinan setiap unit, para staff dan jajaran Pegadaian Syariah Cabang Subrantas Unit Tanah Merah Pekanbaru.

\section{Daftar Pustaka}

Chang, P., Wang, Y., \& Liu, C. (2007). The development of a weighted evolving fuzzy neural network for PCB sales forecasting. 32, 86-96. https://doi.org/10.1016/j.eswa.2005.11.021

Fajar, S. (2011). Aplikasi Logika Fuzzy Dalam Optimasi Produksi Barang. Skripsi. FMIPA, Matematika, Universitas Negeri Yogyakarta.

Hanifah, R. (2017). Penerapan Fuzzy Inference System Untuk Prediksi Hasil Produksi Gula Pasir Denga Metode Mamdani. Skripsi. Saintek, Teknik Informatika, UIN SUNAN KALIJAGA.

Makridakis, S. (1999). Metode dan aplikasi peramalan jilid 1 / Spyros Makridakis, Steven C. Wheelwright, Victor E. McGree; alih bahasa Untung Sus Andriyanto, Abdul Basith. 1999.

Mudrajat, K. (2001). Manajemen Keuangan Internasional: Pengantar Ekonomi dan Bisnis Global (Edisi Kedu). BPFE.

Munawaroh, Normalisa, \& Octaviano, A. (2019). Analisa dan Penerapan Fuzzy Inference System Metode Mamdani untuk Penentuan Penerima Beasiswa. 6(1), 21-52. https://doi.org/10.36079/lamintang.ijai-0601.31

Murni, M., Sihotang Hengki Tamando, \& Verawati, M. N. (2016). Perancangan Sistem Perencanaan Jumlah Produksi Roti Menggunakan Metode Fuzzy Mamdani. Jurnal Mantik Penusa, 20(1), 2088-3943.

Rahmawati, R., Cynthia, E. P., \& Elfi, I. E. (2019). Penerapan Fuzzy Inference System Mamdani Untuk Menentukan Jumlah Pembelian Obat (Studi Kasus: Garuda Sentra Medika). Algoritma : Jurnal Ilmu Komputer Dan Informatika, 3(1), 38. https://doi.org/10.30829/algoritma.v3i1.4437

Rice, S. S. (2014). Analisis Pengaruh Faktor Eksternal Dan Internal. Jurnal Wira Ekonomi Mikroskill, 5, 8-9.

Saleh, A. (2015). Implementasi Metode Fuzzy Mamdani Dalam Memprediksi Tingkat Kebisingan Lalu Lintas. Jurnal Nasional Teknologi Dan Multimedia, 3(1), 3-6-31.

Teeuw, A. (2005). Kamus Belanda Indonesia. Jakarta: PT Gramedia Pustaka Utama.

Untono, M. (2015). Analisis pengaruh pertumbuhan ekonomi, inflasi, nilai 
tukar, indek djia, dan harga minyak dunia terhadap Indek harga saham gabungan. Parsimonia, 2(2), 1-12.

\section{Riwayat Hidup Penulis}

\section{Rahmawati}

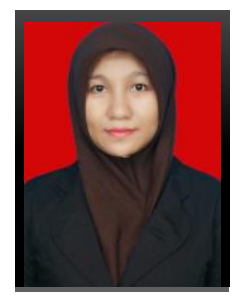

Lahir di Teratak Buluh, 02 Februari 1989. Staf pengajar di Program Studi Matematika Fakultas Sains dan Teknologi UIN Sultan Syarif Kasim Riau. Studi S1 Matematika FMIPA Universitas Riau (UR) Pekanbaru, lulus tahun (2011) dan Studi S2 Matematika Universitas Gadjah Mada (UGM) Yogyakarta, lulus tahun (2015). Penulis saat ini masih aktif sebagai pengajar di Prodi Matematika dengan bidang penelitian yang digeluti adalah aljabar (matematika murni) serta matematika terapan dibidang komputasi numeric dan optimisasi.

\section{Rahima Dina}

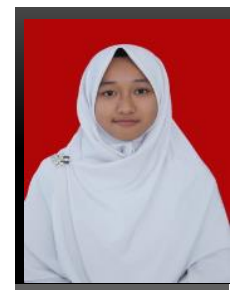

Lahir di Tanjung Jati, 08 Februari 1999. Pelajar di Universitas Islam Negeri Sultan Syarif Kasim Riau. SD Negeri 006 Bangkinang (2011). Mts Daarun Nahdhah Thawalib Bangkinang (2014). Ma Daarun Nahdhan Thawalib Bangkinang (2017).

\section{Wartono}

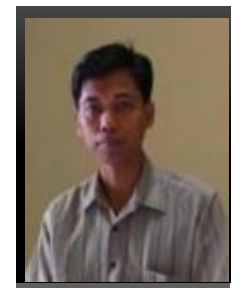

Lahir di Karangampel, 18 Agustus 1973. Pendidikan Sarjana di peroleh di Universitas Riau tahun 1998, sedangkan Pendidikan Magister di peroleh di Universiti Kebangsaan Malaysia tahun 2006. Bidang penelitian yang sedang digelutinya adalah analisa numerik, komputasi persamaan diferensial, dan dinamika fluida. Pada saat ini, penulis merupakan dosen Program Studi Matematika Universitas Islam Negeri Sultan Syarif Kasim Riau. 